\title{
KONVERGENSI INTERNATIONAL FINANCIAL REPORTING STANDARDS (IFRS) DAN MANAJEMEN LABA DI INDONESIA
}

\author{
Yona Octiani Lestari \\ Fakultas Ekonomi,Universitas Islam Negeri Maulana Malik Ibrahim Malang \\ Jl. Gajayana 50 Malang Telp. 0341-551354 Faks. 0341-572533 \\ Email: yonaoctiani@yahoo.com; NO Telephon:08164292906
}

\begin{abstract}
The existence of convergence of accounting standards to IFRS create a new paradigm in the accounting world. This requires the convergence of IFRS accounting standards that have been used to adopt new accounting standards with IFRS. The convergency accounting standards to IFRS increase a variety of influences, in accordance with IFRS characteristics such as : principle based, the use of fair value and more disclosure. Principle Based Standards require more judgment in its application, while the used of fair value items make the financial statements are presented with the actual values, more disclosure would reduce the level of information asymmetry. Convergence of IFRS is expected increasing financial reporting quality, such as, increased camparability and transparency of financial statements. Thus, with the convergence to IFRS expected reduce earnings management opportunities.
\end{abstract}

\section{PENDAHULUAN}

Seiring dengan perkembangan perusahaan multinasional kebutuhan akan standar akuntansi yang berbasis international mutlak diperlukan. Pelaporan keuangan transnasional mensyaratkan perusahaan harus memahami praktik akuntansi ditempat perusahaan tersebut berkedudukan. Pada saat dunia usaha hampir tanpa batas negara, sumberdaya produksi (alat tukar yang paling likuid) yang dimiliki oleh seorang investor disuatu negara tertentu dapat dipindahkan dengan mudah dan cepat ke negara lain, misalnya melalui mekanisme perdagangan di lantai bursa. Dengan kemajuan dan kecanggihan TI pasar modal jutaan atau bahkan miliaran investasi dapat dengan mudah masuk ke lantai pasar modal di seluruh penjuru dunia. Pergerakan mereka tak bisa dihalangi teritori negara. Perkembangan yang mengglobal seperti ini dengan sendirinya menuntut adanya satu standar akuntansi yang dibutuhkan baik oleh pasar modal atau lembaga yang memiliki masalah internal. Tentu saja akan timbul suatu masalah ketika standar akuntansi 
yang dipakai di negara tersebut berbeda dengan standar akuntansi yang dipakai di negara lain. Keanekaragaman standar yang dipakai menjadi kendala investor dan kreditor serta calon investor dan calon kreditor dalam memahami laporan keuangan yang disajikan. Hal tersebut diatas yang mendorong timbulnya standar akuntansi internasional (IFRS) yang dirumuskan oleh IASB (International Accounting Standard Board).

Tetapi beralih ke IFRS bukanlah sekedar pekerjaan mengganti angka-angka di laporan keuangan, tetapi mungkin akan mengubah pola pikir dan cara semua elemen di dalam perusahaan. International Accounting Standards, yang lebih dikenal sebagai International Financial Reporting Standards (IFRS), merupakan standar tunggal pelaporan akuntansi berkualitas tinggi dan kerangka akuntasi berbasiskan prinsip yang meliputi penilaian profesional yang kuat dengan pengungkapan yang jelas dan transparan mengenai substansi transaksi ekonomi, penjelasan hingga mencapai kesimpulan tertentu dan akuntansi terkait transaksi tersebut. Dengan demikian pengguna laporan keuangan dapat dengan mudah membandingkan informasi keuangan entitas antarnegara di berbagai belahan dunia.

Suatu perusahaan akan memiliki daya saing yang lebih besar ketika mengadopsi IFRS dalam laporan keuangannya. Penerapan standar akuntansi yang sama di seluruh dunia juga akan mengurangi masalah-masalah terkait daya banding (comparability) dalam pelaporan keuangan. Adanya kebijakan ini pihak yang paling diuntungkan sudah jelas yaitu investor dan kreditor trans-nasional serta badan-badan internasional. Tidak mengherankan, banyak perusahaan yang telah mengadopsi IFRS mengalami kemajuan yang signifikan saat memasuki pasar modal global. Manfaat dari adanya suatu standar global :

a) Pasar modal menjadi global dan modal investasi dapat bergerak di seluruh dunia tanpa hambatan yang berarti. Standar pelaporan keuangan berkualitas tinggi yang digunakan secara konsisten diseluruh dunia akan memperbaiki efisiensi alokasi local.

b) Investor dapat membuat keputusan yang lebih baik.

c) Perusahaan-perusahaan dapat memperbaiki proses pengambilan keputusan mengenai merger dan akuisisi.

d) Gagasan terbaik yang timbul dari aktivitas pembuatan standar dapat disebarkan dalam mengembangkan standar global yang berkualitas tertinggi (Immanuela, 2009)

Manfaat terpenting dilihat dari sudut pandang akuntansi adalah diharapkan akan meningkatkan kualitas pelaporan keuangan, meningkatnya komparabilitas laporan keuangan 
(relevan) dan transparansi sesuai dengan bukti yang ada (reliable). Salah satunya mengurangi adanya peluang yang memungkinkan munculnya manajemen laba di setiap pelaporan keuangannya. Pembahasan utama dalam tulisan ini adalah konvergensi IFRS dan kemungkinan munculnya praktik manajemen laba pasca diberlakukannya IFRS di Indonesia.

\section{PEMBAHASAN}

\section{Sejarah Perkembangan Standar Akuntansi di Indonesia}

Tonggak sejarah munculnya standar akuntansi di Indonesia diawali dari munculnya pergerakan pasar saham diIndonesia yaitu tahun 1973, pada masa itu merupakan pertama kalinya IAI melakukan kondisifikasi prinsip dan standar akuntansi yang berlaku di Indonesia dalam suatu buku yang disebut "Prinsip Akuntansi Indonesia". Dari tahun ke tahun semakin berkembang sejalan dengan perkembangan dunia bisnis di Indonesia.

Dari serangkaian proses harmonisasi standar dengan standar internasional, konvergensi terhadap IFRS merupakan hal baru dan menjadi pencetus munculnya paradigma baru perkembangan standar di Indonesia.

International Financial Reporting Standards (IFRS) adalah standar, interpretasi dan kerangka kerja dalam rangka Penyusunan dan Penyajian Laporan Keuangan yang diadopsi oleh International Accounting Standards Board (IASB). Banyak standar membentuk bagian dari IFRS. Sebelumnya IFRS ini lebih dikenal dengan nama International Accounting Standards (IAS). IAS diterbitkan antara tahun 1973 dan 2001 oleh Board Of International Accounting Standards Committee Foundation (IASC). Pada tahun 2000 anggota badan ini menyetujui restrukturisasi IASC dan Konstitusi (Anggaran Dasar) baru IASC.

Pada bulan Maret 2001, IASC Trustee mengesahkan bagian B Konstitusi baru IASC dan mendirikan sebuah perusahaan nirlaba Delaware bernama International Accounting Standards Committee Foundations untuk mengawasi IASB. Pada tanggal 1 April 2001 IASB yang baru dibentuk mengambil alih dari IASC tanggungjawab menetapkan Standar Akuntansi Internasional.

Dalam pertemuan pertama Dewan baru itu mengadopsi IAS dan SICs yang sudah ada. Kemudian IASB terus melanjutkan pengembangan standar akuntansi internasional dengan menyebut standar baru mereka itu dengan sebutan International Financial Reporting Standards (IFRS) 


\section{Pada periode 1973-1984,}

Ikatan Akuntansi Indonesia (IAI) telah membentuk Komite Prinsip-prinsip Akuntansi Indonesia untuk menetapkan standar-standar akuntansi, yang kemudian dikenal dengan Prinsip-prinsip Akuntansi Indonesia (PAI).

\section{Pada periode 1984-1994}

Komite PAI melakukan revisi secara mendasar PAI 1973 dan kemudian menerbitkan Prinsip Akuntansi Indonesia 1984 (PAI 1984). Menjelang akhir 1994, Komite standar akuntansi memulai suatu revisi besar atas prinsip-prinsip akuntansi Indonesia dengan mengumumkan pernyataan-pernyataan standar akuntansi tambahan dan menerbitkan interpretasi atas standar tersebut. Revisi tersebut menghasilkan 35 pernyataan standar akuntansi keuangan, yang sebagian besar harmonis dengan IAS yang dikeluarkan oleh IASB.

\section{Pada periode 1994-2004}

Ada perubahan Kiblat dari US GAAP ke IFRS, hal ini ditunjukkan Sejak tahun 1994, telah menjadi kebijakan dari Komite Standar Akuntansi Keuangan untuk menggunakan International Accounting Standards sebagai dasar untuk membangun standar akuntansi keuangan Indonesia. Dan pada tahun 1995, IAI melakukan revisi besar untuk menerapkan standar-standar akuntansi baru, yang kebanyakan konsisten dengan IAS. Beberapa standar diadopsi dari US GAAP dan lainnya dibuat sendiri.

\section{Pada periode 2006-2008}

Merupakan konvergensi IFRS Tahap 1, Sejak tahun 1995 sampai tahun 2010, buku Standar Akuntansi Keuangan (SAK) terus direvisi secara berkesinambungan, baik berupa penyempurnaan maupun penambahan standar baru. Proses revisi dilakukan sebanyak enam kali yakni pada tanggal 1 Oktober 1995, 1 Juni 1999, 1 April 2002, 1 Oktober 2004, 1 Juni 2006, 1 September 2007, dan versi 1 Juli 2009. Pada tahun 2006 dalam kongres IAI (Cek Lagi nanti) X di Jakarta ditetapkan bahwa konvergensi penuh IFRS akan diselesaikan pada tahun 2008. Target ketika itu adalah taat penuh dengan semua standar IFRS pada tahun 2008. Namun dalam perjalanannya ternyata tidak mudah. Sampai akhir tahun 2008 jumlah IFRS yang diadopsi baru 
mencapai 10 standar IFRS dari total 33 standar. Berikut adalah Roadmap konvergensi IFRS di Indonesia:

Gambar 1

Roadmap konvergensi IFRS di Indonesia:

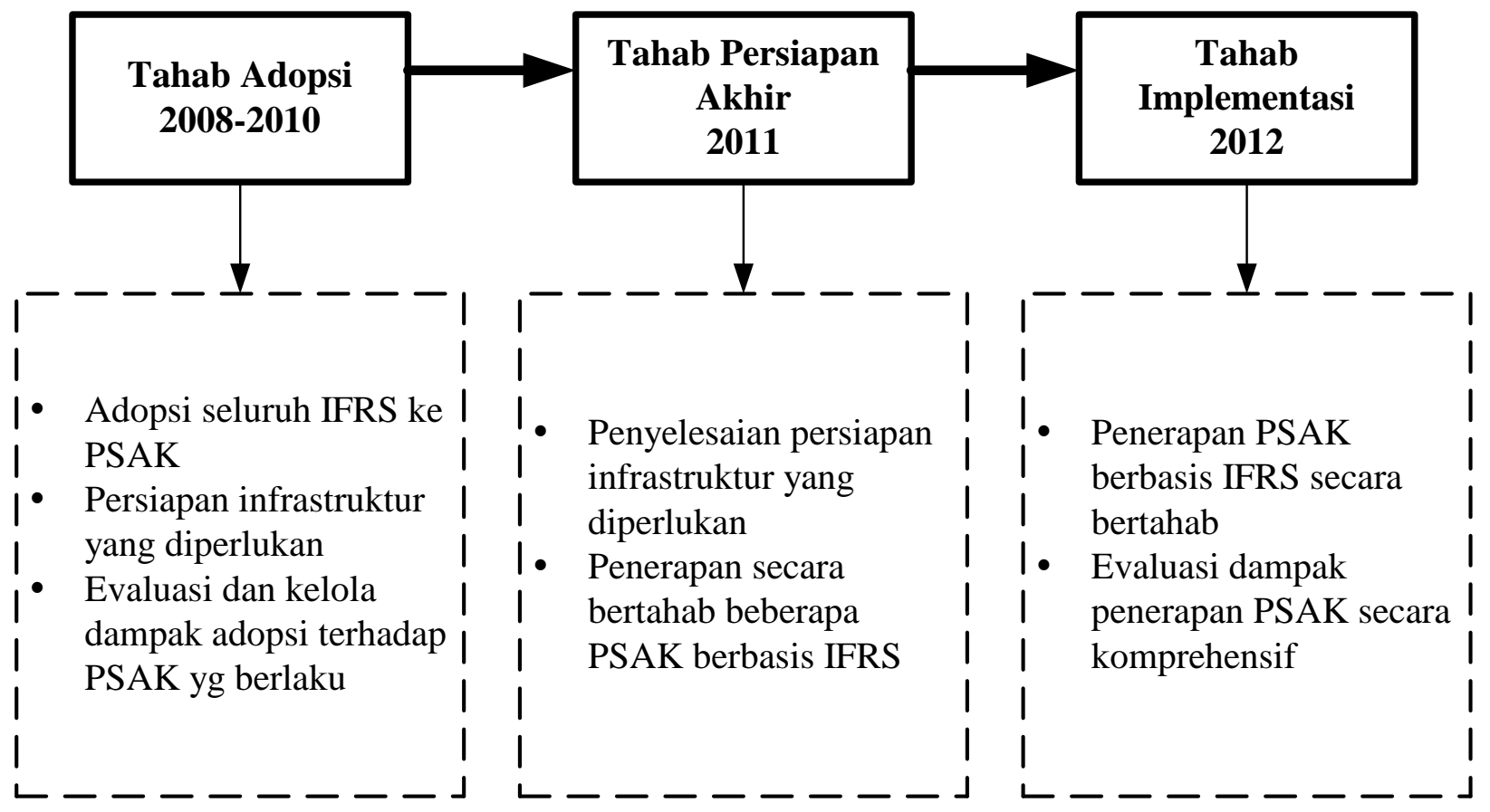

PSAK disahkan 23 Desember 2009:

a. PSAK 1 (revisi 2009): Penyajian Laporan Keuangan

b. PSAK 2 (revisi 2009): Laporan Arus Kas

c. PSAK 4 (revisi 2009): Laporan Keuangan Konsolidasian dan Laporan Keuangan Tersendiri

d. PSAK 5 (revisi 2009): Segmen Operasi

e. PSAK 12 (revisi 2009): Bagian Partisipasi dalam Ventura Bersama

f. PSAK 15 (revisi 2009): Investasi Pada Entitas Asosiasi

g. PSAK 25 (revisi 2009): Kebijakan Akuntansi, Perubahan Estimasi Akuntansi, dan Kesalahan

h. PSAK 48 (revisi 2009): Penurunan Nilai Aset

i. PSAK 57 (revisi 2009): Provisi, Liabilitas Kontinjensi, dan Aset Kontinjensi

j. PSAK 58 (revisi 2009): Aset Tidak Lancar yang Dimiliki untuk Dijual dan Operasi yang Dihentikan

Interpretasi disahkan 23 Desember 2009: 

a. ISAK 7 (revisi 2009): Konsolidasi Entitas Bertujuan Khusus
b. ISAK 9: Perubahan atas Liabilitas Purna Operasi, Liabilitas Restorasi, dan Liabilitas Serupa
c. ISAK 10: Program Loyalitas Pelanggan
d. ISAK 11: Distribusi Aset Nonkas Kepada Pemilik
e. ISAK 12: Pengendalian Bersama Entitas: Kontribusi Nonmoneter oleh Venturer

\section{PSAK disahkan sepanjang 2009 yang berlaku efektif tahun 2010:}

a. PPSAK 1: Pencabutan PSAK 32: Akuntansi Kehutanan, PSAK 35: Akuntansi Pendapatan Jasa Telekomunikasi, dan PSAK 37: Akuntansi Penyelenggaraan Jalan Tol

b. PPSAK 2: Pencabutan PSAK 41: Akuntansi Waran dan PSAK 43: Akuntansi Anjak Piutang

c. PPSAK 3: Pencabutan PSAK 54: Akuntansi Restrukturisasi Utang Piutang bermasalah

d. PPSAK 4: Pencabutan PSAK 31 (revisi 2000): Akuntansi Perbankan, PSAK 42: Akuntansi Perusahaan Efek, dan PSAK 49: Akuntansi Reksa Dana

e. PPSAK 5: Pencabutan ISAK 06: Interpretasi atas Paragraf 12 dan 16 PSAK No. 55 (1999) tentang Instrumen Derivatif Melekat pada Kontrak dalam Mata Uang Asing

\section{PSAK yang disahkan 19 Februari 2010:}
a. PSAK 19 (2010): Aset tidak berwujud
b. PSAK 14 (2010): Biaya Situs Web
c. PSAK 23 (2010): Pendapatan
d. PSAK 7 (2010): Pengungkapan Pihak-Pihak Yang Berelasi
e. PSAK 22 (2010): Kombinasi Bisnis (disahkan 3 Maret 2010)
f. PSAK 10 (2010): Transaksi Mata Uang Asing (disahkan 23 Maret 2010
g. ISAK 13 (2010): Lindung Nilai Investasi Neto dalam Kegiatan Usaha Luar Negeri

\section{Exposure Draft Public Hearing 27 April 2010}

a. ED PSAK 24 (2010): Imbalan Kerja

b. ED PSAK 18 (2010): Program Manfaat Purnakarya

c. ED ISAK 16: Perjanjian Konsesi Jasa (IFRIC 12)

d. ED ISAK 15: Batas Aset Imbalan Pasti, Persyaratan Pendanaan Minimum dan Interaksinya.

e. ED PSAK 3: Laporan Keuangan Interim 
f. ED ISAK 17: Laporan Keuangan Interim dan Penurunan Nilai

\section{Exposure Draft PSAK Public Hearing 14 Juli 2010}

a. ED PSAK 60: Instrumen Keuangan: Pengungkapan

b. ED PSAK 50 (R 2010): Instrumen Keuangan: Penyajian

c. ED PSAK 8 (R 2010): Peristiwa Setelah Tanggal Neraca

d. ED PSAK 53 (R 2010): Pembayaran Berbasis Saham

\section{Exposure Draft PSAK Public Hearing 30 Agustus 2010}

a. ED PSAK 46 (Revisi 2010) Pajak Pendapatan

b. ED PSAK 61: Akuntansi Hibah Pemerintah Dan Pengungkapan Bantuan Pemerintah

c. ED PSAK 63: Pelaporan Keuangan dalam Ekonomi Hiperinflasi

d. ED ISAK 18: Bantuan Pemerintah-Tidak Ada Relasi Specifik dengan Aktivitas Operasi

e. ED ISAK 20: Pajak Penghasilan-Perubahan dalam Status Pajak Entitas atau Para Pemegang Sahamnya

\section{Kendala dalam harmonisasi PSAK ke dalam IFRS}

a. Dewan Standar Akuntansi yang kekurangan sumber daya

b. IFRS berganti terlalu cepat sehingga ketika proses adopsi suatu standar IFRS masih dilakukan, pihak IASB sudah dalam proses mengganti IFRS tersebut.

c. Kendala bahasa, karena setiap standar IFRS harus diterjemahkan ke dalam bahasa Indonesia dan acapkali ini tidaklah mudah.

d. Infrastuktur profesi akuntan yang belum siap. Untuk mengadopsi IFRS banyak metode akuntansi yang baru yang harus dipelajari lagi oleh para akuntan.

e. Kesiapan perguruan tinggi dan akuntan pendidik untuk berganti kiblat ke IFRS.

f. Support pemerintah terhadap issue konvergensi.

\section{Manfaat Konvergensi IFRS secara umum adalah:}

Penyesuaian terhadap IFRS memberikan manfaat terhadap keterbandingan laporan keuangan dan peningkatan transparansi. Melalui penyesuaian maka laporan keuangan perusahaan Indonesia akan dapat diperbandingkan dengan laporan keuangan perusahaan dari negara lain, sehingga 
akan sangat jelas kinerja perusahaan mana yang lebih baik dan dapat meningkatkan kualitas Standar Akuntansi Keuangan. Selain itu program konvergensi IFRS juga mengurangi biaya modal (cost of capital) dengan membuka peluang penggalangan dana melalui pasar modal secara global, meningkatkan investasi global, dan mengurangi beban penyusunan laporan keuangan, meningkatkan kredibilitas dan kegunaan laporan keuangan, meningkatkan komparabilitas laporan keuangan dan menciptakan efisiensi penyusunan laporan keuangan.

Disisi lain tujuan konvergensi IFRS adalah agar laporan keuangan berdasarkan PSAK tidak memerlukan rekonsiliasi signifikan dengan laporan keuangan berdasarkan IFRS dan kalaupun ada diupayakan hanya relatif sedikit sehingga pada akhirnya laporan auditor menyebut adanya kesesuaian dengan IFRS.

Secara rinci manfaat adopsi IFRS adalah sebagai berikut:

a. Memudahkan pemahaman atas laporan keuangan dengan penggunaan Standar Akuntansi Keuangan yang dikenal secara internasional (enhance comparability).

b. Meningkatkan arus investasi global melalui transparansi.

c. Menurunkan biaya modal dengan membuka peluang fund raising melalui pasar modal secara global.

d. Menciptakan efisiensi penyusunan laporan keuangan.

e. Meningkatkan kualitas laporan keuangan, dengan antara lain, mengurangi kesempatan untuk melakukan earning management

- Reklasifikasi antar kelompok surat berharga (securities) dibatasi cenderung dilarang.

- Reklasifikasi dari dan ke FVTPL, DILARANG

- Reklasifikasi dari L\&R ke AFS, DILARANG

- Tidak ada lagi extraordinary items

\subsection{Konvergensi IFRS dan Tantangannya}

International Financial Reporting Standards (IFRS) memang merupakan kesepakatan global standar akuntansi yang didukung oleh banyak negara dan badan-badan internasional di dunia. Popularitas IFRS ditingkat global semakin meningkat dari waktu ke waktu. Kesepakatan G-20 di Pittsburg pada tanggal 24-25 September 2009 menyatakan bahwa otoritas yang mengawasi aturan akuntansi internasional harus meningkatkan standar global pada bulan Juni 2011 untuk mengurangi kesenjangan aturan di negara-negara anggota G-20. Sejak tahun 2008 
diperkirakan sekitar 80 negara mengharuskan perusahaan yang telah terdaftar di dalam bursa efek global menerapkan IFRS dalam mempersiapkan dan mempresentasikan laporan keuangannya. Dan akhirnya IFRS menjadi One Global Accounting Standards. Dan telah tercatat 150 negara menggunakan standar IFRS sebagai pedoman Pelaporan keuangannya.

Demikian halnya dengan Indonesia, sebagai salah satu negara G-20 juga telah memutuskan untuk konvergensi ke IFRS. Konvergensi sendiri berarti to became similar or the same. Dengan demikian konvergensi IFRS dapat diartikan membuat standar akuntansi suatu negara sama dengan IFRS (Kartikahadi, 2010)

Konvergensi IFRS dapat dilakukan dengan 2 cara yaitu pertama adopsi (mengambil langsung IFRS), dan kedua harmonisasi secara sederhana (mensinergikan standar yang dimiliki dengan standar akuntansi internasional atau tidak mengikuti sepenuhnya standar akuntansi internasional)

Dan dalam perkembangannya maka standar akuntansi yang semula Single Standards telah berubah menjadi Triple Standards yaitu SAK Berbasis IFRS yaitu standar yang memiliki fungsi fidusia dan mempunyai pertanggungjawaban publik, SAK SAS (Standar Akuntansi Syariah) dan SAK ETAP (Entitas Tanpa Akuntabilitas Publik) yang digunakan oleh perusahaan kecil dan menengah atau perusahaan yang tidak memiliki fungsi fidusia.

\section{Perbedaan US GAAP dan IFRS}

\section{Nilai Wajar}

Sesuai standar akuntansi terdahulu yang bukan konvergensi IFRS pengukuran setiap transaksi menggunakan prinsip historical cost yaitu merupakan jumlah kas atau setara kas yang dibayarkan atau nilai wajar imbalan lain yang diserahkan atau memperoleh asset pada saat perolehan atau konstruksi, atau jika dapat diterapkan jumlah yang dapat distribusikan langsung ke asset pada saat pertama kali diakui sesuai dengan persyaratan tertentu (PSAK 19, revisi 2009). Kelemahan dari historical cost adalah kurang mencerminkan kondisi yang sebenarnya. Hal ini biasanya memungkinkan peluang pihak menejemen untuk melakukan manajemen laba. Misalnya pada kondisi terburuk yaitu kinerja perusahaan sedang tidak bagus maka nilai asset yang nilai wajar asset tersebut pada tanggal pelaporan lebih besar dari nilai tercatatnya maka pihak manajemen akan berupaya menjual asset tersebut. Sehingga muncul keuntungan atas penjualan asset yang 
dilaporkan dalam laporan laba rugi perusahaan. Keunggulan menggunakan prinsip historical cost adalah bahwa historical cost lebih objektif dan lebih verifiable karena didasarkan pada transaksi. Standar yang konvergensi terhadap IFRS lebih condong pada penggunaan nilai wajar, terutama property investasi, beberapa asset tidak berwujud, asset keuangan dan asset biologis (Cahyati, 2011). Dengan demikian diperlukan sumberdaya yang kompeten untuk menghitung nilai wajar atau bahkan perlu menyewa jasa penilai terutama untuk asset yang tidak memiliki nilai pasar aktif. Nilai wajar (fair value) adalah suatu jumlah yang dapat digunakan sebagai dasar pertukaran asset atau penyelesaian kewajiban antara pihak yang paham (knowledgeable) dan berkeinginan untuk melakukan transaksi wajara (IAI, 2009). Keuntungan menggunakan nilai wajar adalah bahwa pos-pos asset dan liabilitas yang dimiliki lebih mencerminkan nilai yang sebenarnyapada saat tanggal laporan keuangan. Ada argument yang menolak penggunaan nilai wajar yang menyatakan bahwa penggunaan nilai wajar menyebabkan volatilitas dalam laporan keuangan dan mengurangi prediksi laba. Namun jika penggunaan volatilitas tersebut justru mengungkapkan realitas ekonomi yang sebenarnya maka peralihan ini diharapkan dapat mengurangi manajemen laba, dan bukan sebaliknya (Siregar, 2010).

\section{Principal Based}

Sebelum berlakunya konvergensi IFRS standar akuntansi di Indonesia menggunakan US GAAP yang dirumuskan oleh FASB. US GAAP merupakan standar berbasis aturan (rules based). Standar yang berbasis aturan ini akan meningkatkan konsistensi dan keterbandingan antar perusahaan dan antar waktu, namun disisi lain tidak relevan karena ketidakmapuan standar untuk merefleksikan kejadian ekonomi entitas yang berbeda antar perusahaan dan antar waktu. Standar dengan basis aturan menjadi cikal bakal munculnya aturan-aturan akuntansi baru untuk industry tertentu, misalnya akuntansi penyelenggaraan jalan tol, akuntansi koperasi, akuntansi perbankan an akuntansi kehutanan. Secara prinsip sebetulnya terdapat kesamaan standar akuntansi terutama aturan pengakuan pendapatan dan pengakuan asset. Semakin banyak aturan-aturan baru yang muncul melengkapi standar yang telah ada justru semakin menjadi celah kelemahan aturan tersebut, jika kondisinya seperti itu maka semakin rawan terjadi pelanggaran. Dan hal ini memberikan kesempatan bagi manajemen melakukan smoothing income yang memicu munculnya manajemen laba. Auditorpun menjadi lebih sulit menolak manipulasi yang dilakukan oleh manajemen ketika ada aturan detail yang menjustifikasinya. 


\section{Pengungkapan lebih rinci dan detail}

IFRS mensyaratkan pengungkapan berbagai informasi tentang risiko baik kualitatif maupun kuantitatif. Pengungkapan dalam laporan keuangan harus sejalan dengan data/informasi yang dipakai untuk pengambilan keputusan yang diambil oleh manajemen. Tingkat pengungkapan yang makin mendekati pengungkapan penuh (full disclosure) akan mengurangi tingkat asimetri informasi (ketidakseimbangan informasi) antara manajer dan pihak pengguna laporan keuangan. Asimetri informasi adalah kondisi dimana manajer mempunyai informasi superior dibandingkan dengan pihak lain. Oleh karena itu manajer akan cenderung melakukan disfuctional behavior dengan melakukan manajemen laba terutama jika informasi tersebut terkait dengan pengukuran kinerja manajer. Jadi dapat disimpulkan kondisi asimetri informasi inilah sebenarnya yang menyebabkan terjadinya manajemen laba. Dengan kata lain tingkat pengungkapan memiliki hubungan negatif dengan manajemen laba sejalan dengan penelitian yang dilakukan oleh Siregar dan Bahtiar (2003)

Tabel 1

\begin{tabular}{|c|c|c|}
\hline TOPIK & US GAAP & PSAK Baru \\
\hline Komponen Laporan Keuangan & 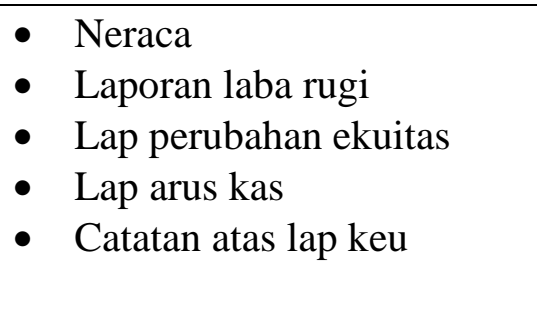 & $\begin{array}{l}\text { - Lap posisi keuangan } \\
\text { - Laba rugi komprehensif } \\
\text { - Lap perubahan ekuitas } \\
\text { - Lap arus kas } \\
\text { - Catatan atas lap keu } \\
\text { - Lap posisi keu awal }\end{array}$ \\
\hline $\begin{array}{l}\text { Asset Tetap } \\
\text { - Pengakuan }\end{array}$ & $\begin{array}{l}\text { Aktiva tetap diakui sebesar } \\
\text { biaya perolehannya } \\
\text { Biaya perolehan mencakup } \\
\text { semua pengeluaran utk } \\
\text { mendapatkan asset tersebut } \\
\text { hingga siap digunakan }\end{array}$ & $\begin{array}{l}\text { Sama } \\
\text { Sama }\end{array}$ \\
\hline - Penentuan biaya & $\begin{array}{l}\text { Disusutkan selama masa } \\
\text { manfaat } \\
\text { Tidak ada petunjuk khusus } \\
\text { yang berhubungan dg } \\
\text { penyusutan }\end{array}$ & $\begin{array}{l}\text { Sama } \\
\text { Suatu asset tetap disusutkan } \\
\text { meskipun asset tersebut tidak } \\
\text { digunakan (idle), namun asset } \\
\text { tdk lancar yg dimiliki utk }\end{array}$ \\
\hline
\end{tabular}




\begin{tabular}{|c|c|c|}
\hline & $\begin{array}{l}\text { Masa manfaat, nilai sisa dan } \\
\text { metode penyusutan ditinjau } \\
\text { scr berkala dengan alas an } \\
\text { yang jelas } \\
\text { Perubahan pd masa manfaat } \\
\text { suatu aktiva dicatat prospektif } \\
\text { sbg perubahan estimasi } \\
\text { akuntansi } \\
\text { Ketika suatu asset tetap terdiri } \\
\text { dr komponen individu yang } \\
\text { berbeda metode atu tariff } \\
\text { penyusutan yang sesuai, } \\
\text { masing2 komponen dicatat } \\
\text { scr terpisah }\end{array}$ & $\begin{array}{l}\text { dijual tdk disusutkan } \\
\text { Masa manfaat, nilai sisa dan } \\
\text { metode penyusutan hrs } \\
\text { direview setiap tgl neraca (tiap } \\
\text { tahun) dg alas an pola } \\
\text { konsumsi atau pemanfaatan } \\
\text { ekonomi atas asset tersebut } \\
\text { Sama }\end{array}$ \\
\hline - Revaluasi & $\begin{array}{l}\text { Umunya asset tetap tidak } \\
\text { dapat dinilai kembali ke fair } \\
\text { value kecuali jika penilaian } \\
\text { kembali } \\
\text { berdasarkan } \\
\text { pemerintah. }\end{array}$ & $\begin{array}{l}\text { Aktiva tetap dapat dinilai } \\
\text { kembali utk fair value jika } \\
\text { semua item dikelas yg sama } \\
\text { dinilai kembali pd wkt yg } \\
\text { sama dan revaluasi disimpan } \\
\text { up to date. }\end{array}$ \\
\hline - Impairment & $\begin{array}{l}\text { Tdk ada panduan khusus } \\
\text { tentang apakah nilai dapat } \\
\text { kompensasi atas kerugian } \\
\text { atau penurunan nilai dpt di } \\
\text { offset thd nilai aktiva yg } \\
\text { hilang atau penurunan nilai. }\end{array}$ & $\begin{array}{l}\text { Kompensasi atas kerugian atau } \\
\text { penurunan nilai tidak dapat di } \\
\text { offset thd nilai tercatat aktiva } \\
\text { yg hilang atau turun }\end{array}$ \\
\hline - Disposal & $\begin{array}{l}\text { Keuntungan atau kerugian } \\
\text { yang timbul dari penghentian } \\
\text { atau pelepasan aktiva tetap } \\
\text { diakui sbg keuntungan atau } \\
\text { kerugian }\end{array}$ & Sama \\
\hline
\end{tabular}

\section{Manajemen Laba}

\section{Definisi}

Konsep manajemen laba menggunakan pendekatan teori keagenan. Teori Agency berfokus pada dua individu yaitu principal dan agen yang masing-masing pihak yaitu agen dan principal berusaha untuk memaksimalkan kepentingan dirinya sendiri, sehingga menimbulkan konflik 
kepentingan diantara principal dan agen (Scott,1997:240). Menurut Scott (1997) Seorang manajer akan memilih satu metoda atau kebijakan tertentu yang diperbolehkan GAAP dengan harapan dapat memaksimumkan utility mereka atau meningkatkan nilai perusahaan. Cara yang digunakan manajer untuk mempengaruhi angka laba sistematis dan sengaja dengan cara memilih kebijakan akuntansi dan prosedur akuntansi tertentu bertujuan memaksimumkan utility manajer dan harga saham, perilaku diatas disebut sebagai earnings management (earning management). Earning Management merupakan intervensi dari pihak manajemen untuk mengatur laba yaitu dengan menaikkan atau menurunkan laba akuntansi dengan memanfaatkan atau kelonggaran penggunaan metode dan prosedur akuntansi. Karena standar akuntansi memperbolehkan perusahaan untuk memilih metode akuntansi (Cahyati, 2011)

\section{Motivasi}

Motivasi untuk melakukan earnings management biasanya timbul akibat "pressure" baik dari dalam maupun dari luar perusahaan. Pressure dari dalam perusahaan biasanya berhubungan dengan perfoma keuangan yang tidak mencapai target yang telah ditentukan. Motivasi ini semakin kencang bila performa keuangan berhubungan dengan "reward" berupa insentive keuangan, seperti bonus atau untuk mendapatkan kompensasi yang maksimal (Octiani, 2010).

Sedangkan motivasi dari luar, biasanya justru datang dari pihak top manajemen yang ingin menunjukkan bahwa berkat kepemimpinan mereka performa keuangan perusahaan telah menjadi lebih baik. Terutama bila perusahaan ini adalah perusahaan go publik, maka pihak top manajemen ingin menunjukkan kepada para pemegang saham bahwa kepemimpinan mereka dapat diandalkan. Kecenderungannya akan lebih kuat, bila data aktual hanya berada dibawah sedikit dari target yang diinginkan. Maka earnings management berfungsi untuk "menyempurnakannya" menjadi laporan keuangan yang lebih baik.

Dalam kaitannya dengan pasar modal, earnings management juga dilakukan oleh pihak manajemen bila terdapat "gap" antara perfoma perusahaan dengan ekspektasi dari para analisis pasar modal. Manajemen biasanya secara agresif akan membuat laporan keuangan sesuai dengan "forecast" dari pihak analis pasar modal.

Motivasi lain adalah untuk membuat laporan keuangan lebih atraktif dan menarik dalam upaya mengajukan aplikasi pinjaman (loan aplication) atau melaksanakan IPO (Initial Public Offering). 
Bahkan dalam melakukan pengajuan aplikasi pinjaman, terdapat indikasi bahwa earnings management dilakukan justru untuk membuat laporan keuangan menjadi "sangat menyedihkan", dengan tujuan untuk mendapatkan belas kasihan suntikan dana dari pihak bank. Dalam Intan (2000) menunjukkan motivasi earnings management dikelompokkan menjadi 3 yaitu motivasi pasar modal, motivasi kontrak dan motivasi pemerintah.

\section{a. Motivasi Pasar Modal}

Informasi akuntansi oleh investor dan analis keuangan bermanfaat membantu menilai saham. Kesempatan ini digunaklan oleh manajer untuk memanipulasi laba dalam usaha mempengaruhi kinerja saham dalam jangka pendek. Penelitian earnings management pada pasar saham difokuskan atas perilaku unexpected accruals.

Menurut DeAngelo (1988) menginvestigasi manajer dari 64 perusahaan terdaftar di NYSE (New York Stock Exchange). Manajer mengusulkan untuk membeli kembali saham yang beredar di masyarakat. Sampel diambil dari tahun 1973-1982. Hipotesis yang diajukan adalah manajer dapat membayar dengan harga lebih murah pada waktu membeli saham tersebut. Akan tetapi dia menemukan sedikit bukti earnings management oleh perusahaan yang melakukan pembelian kembali saham dengan menurunkan laba melalui discretionary accruals.

Perry dan Williams (1994) menguji unexpected accruals mengendalikan perubahan dalam pendapatan dan modal deprisiabel. Kecuali itu dilakukan dengan menambah sampel perusahaan sebanyak 175 perusahaan yang melakukan pengambilalihan saham pada thun 1981-1988. Hasil nya menunjukkan bahwa perusahaan yang manajernya ikut berpartisipasi dalam pengambilalihan saham terdapat bukti melakukan earnings management dengan cara menurunkan laba melalui discretionary accrual pada perioda sebelum dilakukan pengambilallihan. Hal tersebut dapat ditunjukkan dengan unexpected accruals negative (penurunan laba) sebelum management buyout.

Penelitian yang dilakukan oleh Teoh, Welch dan Wong (1998) adalah menaikkan laba selama perioda penerbitan saham. Perusahaan melaporkan positif (peningakatan laba) unexpected accruals sebelum penawaran saham. Pada saat IPO perusahaan berusaha menaikkan earnings dengan menggunakan akrual. Setelah tiga tahun IPO kinerja sahamnya mengalami penurunan $20 \%$ dari laporan keuangan saat IPO.

Bidang perbankan dan asuransi juga ada earnings management yang dilakukan oleh manajemen. Penelitian yang dilakukan oleh Baever, Eger, Ryan dan Wolfson (1989), Beatty, 
Chamberlain dan Magliolo (1995) melihat earnings management yang dilakukan oleh perbankan dan lembaga asuransi. Hasilnya menunjukkan adanya tingkat accrual positif. Penelitian ini dipertegas oleh penelitian Setiawati (1999) meneliti indikasi earnings management pada laporan keuangan yang dilaporkan lembaga perbankan pada Bank Indonesia karena disinyalir adanya asimetri informasi antara Bank Indonesia dan Bank-bank yang ditanganinya. Hasilnya bank yang mengalami penurunan kesehatan lebih banyak melakukan manipulsi laba.

\section{b. Motivasi Kontrak}

Motivasi kontrak berkaitan dengan utang jangka panjang, yaitu manajer menaikkan laba bersih untuk mengurangi kemungkinan perusahaan mengalami technical default. Healy (1985) menemukan banyak perencanaan bonus yang lebih rendah atau lebih tinggi dari batas minimal atau maksimal bonus yang harus dibayar. Jika manajer perusahaan mendapatkan laba yang diperoleh lebih rendah dari target laba maka manajer akan melakukan manipulasi laba dengan mentransfer laba yang diperoleh perioda sekarang ke perioda mendatang dengan harapan akan mendapatkan bonus.

Pada penelitian Sweeney (1994) bahwa perusahaan melakukan pengelolaan modal kerja dan ekuitas pemegang saham, dengan cara meningkatkan laba lima tahun kebelakang sehingga rasio debt to equity dan interest coverage relative pada posisi yang menguntungkan.

Penelitian yang menguji debt equity hypothesis dengan mengevaluasi tingkat akrual 94 perusahaan yang melanggar perjanjian kredit. Penelitian dengan menggunakan model penelitian

Jones (1991) untuk memproksikan normal akrual. Hasil penelitian membuktikan bahwa satu perioda sebelum pelanggaran perjanjian kredit, perusahaan merekayasa akrual. Hal ini dapat dilihat abnormal accrual perioda tersebut positif dan signifikan.

\section{c. Motivasi Regulasi.}

Pemerintah mewajibkan laporan keuangan dalam bentuk angka akuntansi akhirnya juga menimbulkan masalah earnings management yang dilakukan oleh manajemen. Hal ini timbul karena manajer memanfaatkan kelemahan akuntansi yang menggunakan estimasi akrual dan pemilihan metoda akuntansi.

Jones (1991) pada penelitian yang dilakukan menghasilkan beberapa produsen yang melaporkan laba yang menurun dengan menggunakan discretionary accrual untuk mempengaruhi keputusan karena adanya regulasi import. 
Pada tahun 1997 dipertegas oleh penelitian Hall dan Stammerjohan (1997) meneliti perusahaan minyak yang mengalami damage awards. Hal yang dilakukan perusahaan adalah meminimalkan pinalti, dengan cara pemilihan kebijakan akuntansi yang menurunkan laba. Alasan manajer melakukan hal tersebut karena dalam penentuan keputusan pengaadilan berdasar atas data akuntansi dengan mempertimbangkan kondisi keuangan. Perusahaan akan berusaha menurunkan laba perusahaan untuk mempengaruhi keputusan pengadilan.

\section{Teknik Manajemen Laba}

Manajemen laba dapat dilakukan dengan berbagai cara, salah satunya menyiasati beberapa kelonggaran yang diperbolehkan dalam standar akuntansi keuangan. Seperti dikutip oleh Setiawan dan Naim (2000) dalam Pramudji dalam Cahyati (2000), manajemen laba dapat dilakukan dengan cara sebagai berikut :

a. Memanfaatkan peluang untuk membuat estimasi akuntansi yaitu manajemen dapat mempengaruhi laba melalui perkiraan terhadap estimasi akuntansi antara lain estimasi tingkat piutang tak tertagih, estimasi kurun waktu depresiasi asset tetap atau amortisasi asset tidak berwujud, estimasi biaya garansi, dll

b. Mengubah metode akuntansi, yaitu melakukan perubahan metode akuntnsi yang digunakan untuk mencatat suatu transaksi. Contoh mengubah depresiasi asset tetap dari metode jumlah angka tahun ke metode garis lurus.

c. Menggeser periode biaya atau pendapatan, yaitu melakukan pergeseran periode biaya atau pendapatan. Misalnya dengan menunda atau mempercepat pengeluaran penelitian sampai pada periode akuntansi berikutnya, menunda atau mempercepat pengeluaran promosi sampai periode berikutnya, mempercepat atau menunda pengeluaran promosi sampai periode berikutnya, mempercepat atau menunda pengiriman produk ke pelanggan, mengatur penjualan asset tetap perusahaan

\section{Implikasi Manajemen laba}

Fenomena manajemen laba seperti dua sisi mata uang. Pada satu sisi terang, earnings management adalah produk yang 'legitimate', sedangkan disisi lain (sisi gelap), earnings management dianggap sebagai produk dari suatu tindakan yang 'immoral' dan 'unethical'. Earnings management oleh sebagian kalangan dianggap sebagai 'proffesional judgement' atas 
laporan keuangan, tetapi dapat menyesatkan (mislead) pihak stakeholder dalam melakukan interpretasi terhadap performa ekonomi (economic perfomance) suatu perusahaan.

Dengan demikian dapat disimpulkan bahwa pihak manajemen telah dengan sengaja melakukan tindakan manipulasi atau tindakan lainnya yang dapat mempengaruhi laporan keuangan. Konsekuensinya akan lebih luas bila earnings management dilakukan oleh manajemen perusahaan go publik, pihak insvestor akan terlihat 'bodoh' bila mempercayai laporan keuangan tersebut. Biasanya hal ini dilakukan oleh pihak manajemen yang mempunyai keyakinan kuat bahwa pihak insvestor tidak mempunyai akses informasi ke dalam perusahaan, sehingga investor akan melihat laporan keuangan tersebut sebagai laporan yang true report.

Bila manajemen tidak mempengaruhi atau memanipulasi laporan keuangan, maka dapat disimpulkan bahwa earning quality telah bernilai positif. Data-data yang dilaporkan berarti dapat dipercaya dan dapat diandalkan. Tanpa campur tangan earnings management, berarti laporan keuangan telah benar-benar merefleksikan kondisi sebenarnya suatu perusahaan dan akan membantu pihak stakeholder dalam memprediksi performa ekonomi perusahaan tersebut dimasa datang. Sebagian kalangan - terutama kalangan akademisi, melihat bahwa earnings managemet terlihat "sangat menakutkan", karena aktivitas ini sangat berhubungan dengan moralitas dari manajemen.

Menurut Subiyantoro dan Triyuwono (2004:128) laporan keuangan sangat dibutuhkan oleh pemakai informasi karena dapat digunakan untuk memenuhi 4 (empat) hal, yaitu: 1) Pemilik perusahaan, 2) Keberlangsungan usaha, 3) Investasi masa depan, dan 4) Prestasi (manajemen). Laporan laba bagi kepentingan pemilik perusahaan berarti laporan laba berguna sebagai isi informasi laba dalam penyajian laporan keuangan dan setidaknya dapat menambah keuntungan secara pribadi pemilik perusahaan. Laporan laba menyangkut keberlangsungan usaha berarti hal ini didasarkan pada asumsi bahwa usaha dapat berlangsung bila ada ketersediaan kas sebagai modal usaha dalam perusahaan. Laporan laba berguna bagi investasi masa depan berarti informasi ini dapat digunakan sebagai bahan pertimbangan untuk keputusan masa depan menyangkut investasi usaha. Laporan laba berguna bagi peningkatan prestasi karyawan berarti laporan ini dapat mempengaruhi posisi atau kedudukan serta prestasi karyawan.

Informasi laba dalam praktiknya dapat mempengaruhi perilaku para pemakai informasi laporan keuangan, khususnya pihak investor dan kreditor. Apalagi dalam negara yang dalam perekonomiannya terdapat mekanisme pasar modal di dalamnya. Laba (earnings), kemampuan 
menghasilkan laba (earning power), dan kemampuan menciptakan kas (cash generating power) badan usaha dianggap sebagai indikator yang dapat mempengaruhi perilaku partisipan di pasar modal (Suwardjono, 2004:159). Informasi laba ini dibutuhkan oleh investor dan kreditor sebagai dasar keputusan terhadap tingkat pengembalian modal yang mereka investasikan.

Karena besarnya manfaat yang diberikan oleh laporan keuangan inilah, maka dibentuk sebuah aturan dalam proses pelaporan keuangan (financial reporting) yang disebut dengan Prinsip Akuntansi Berterima Umum (PABU) atau Generally Accepted Accounting Principles (GAAP). PABU adalah rerangka pedoman yang terdiri atas standar akuntansi dan sumbersumber lain yang didukung berlakunya praktik akuntansi secara resmi (yuridis), teoretis, dan praktis. Standar akuntansi berarti semua konsep, ketentuan, prosedur, metoda, dan teknik yang tersedia secara teoretis maupun praktis dalam proses pelaporan keuangan. Sedangkan sumbersumber lain bisa dalam bentuk praktik yang tidak diatur dalam standar akuntansi termasuk peraturan badan autoratif lain, kebiasaan dan konvensi yang membentuk praktik pelaporan keuangan yang sehat (sound practices) (Suwardjono, 2004:122).

Tujuan dibentuknya Prinsip-Prinsip Akuntansi Berterima Umum (PABU) sebagai aturan dalam pelaporan keuangan adalah untuk menyeragamkan proses pelaporan keuangan (financial reporting) berikut hasilnya berupa laporan keuangan (financial statement) pada setiap entitas bisnis yang ada dalam sebuah negara, sehingga dapat mempermudah dalam proses pengauditan (auditing) atas kewajaran dalam pelaporannya. Tujuan lainnya adalah untuk mengukur tingkat keterbandingan (comparability) antara laporan keuangan entitas bisnis yang satu dengan yang lainnya, sehingga akan memperlihatkan keterbandingan (comparability) tingkat kinerja keuangannya.

Dengan diterapkannya Prinsip-Prinsip Akuntansi Berterima Umum (PABU) oleh setiap entitas bisnis, maka diharapkan laporan keuangan yang dihasilkan nantinya memiliki kualitas yang tinggi. Kualitas laporan keuangan yang tinggi dapat dilihat dari karakteristik-karakteristik kualitatif yang mendukungnya. Ikatan Akuntan Indonesia (2002) menyatakan bahwa terdapat empat karakteristik kualitatif pokok, yaitu dapat dipahami, relevan, keandalan, dan dapat diperbandingkan. Laporan keuangan dapat dipahami berarti laporan keuangan memiliki tingkat kemudahan yang tinggi untuk segera dapat dipahami oleh pemakai. Laporan keuangan relevan berarti informasi yang dihasilkan oleh laporan keuangan harus relevan untuk memenuhi kebutuhan pemakai dalam proses pengambilan keputusan. Laporan keuangan memiliki kualitas 
andal jika bebas dari pengertian yang menyesatkan, kesalahan material, dan dapat diandalkan pemakainya sebagai penyajian yang jujur dari yang seharusnya disajikan atau yang secara wajar diharapkan dapat disajikan. Laporan keuangan dapat diperbandingkan berarti laporan keuangan harus dapat diperbandingkan antar perode untuk mengidentifikasi kecenderungan (trend) posisi dari kinerja keuangan.

Dalam tataran normatif, Prinsip-Prinsip Akuntansi Berterima Umum (PABU) di atas memang dapat memberikan jaminan atas kualitas laporan keuangan yang diterbitkan oleh entitas bisnis. Tetapi dalam tataran praktis, Standar Akuntansi (sebagai salah satu aspek dari PABU) memiliki keterbatasan-keterbatasan yang dapat menjadikan laporan keuangan menjadi kurang andal (reliable). Keterbatasan-keterbatasan tersebut menurut Surifah (2000) di antaranya adalah: 1) Fleksibilitas penerapan metode akuntansi yang menyebabkan peluang bagi manajemen untuk melibatkan subyektifitas dalam menyusun metode akuntansi yang dipilih, dan 2) Penentuan waktu untuk pengeluaran-pengeluaran yang bersifat discretionary dapat dipergunakan oleh manajemen untuk mempengaruhi laba, yaitu dengan mempercepat atau menunda pengeluaranpengeluaran tersebut dan menggesernya pada periode-periode yang lain. Fraser (dalam Surifah, 2000) juga menyebutkan keterbatasan laporan keuangan lainnya yaitu laporan keuangan berisi data masa lalu (historical data) sehingga memiliki keterbatasan informasi jika dikaitkan dengan likuiditas perusahaan pada masa yang akan datang.

Keterbatasan laporan keuangan di atas, pada praktiknya menimbulkan aktivitas manajemen laba (earnings management) oleh pihak manajemen perusahaan terhadap laporan keuangannya. Manajemen laba adalah tindakan yang ditujukan untuk memaksimumkan utilitas manajer dan cenderung untuk menguntungkan diri mereka (manajer) sendiri dengan cara mempengaruhi proses pelaporan keuangan. Sebagaimana yang dinyatakan oleh Setiawati dan Na'im (2000) bahwa manajemen laba adalah campur tangan manajemen dalam proses pelaporan keuangan eksternal dengan tujuan untuk menguntungkan diri sendiri. Berikut juga Scott (1997:369) yang menyatakan bahwa :

manajemen laba adalah cara yang digunakan oleh manajer untuk mempengaruhi angka laba secara sistematis dan sengaja dengan cara memilih kebijakan akuntansi dan prosedur akuntansi tertentu yang bertujuan untuk memaksimumkan utilitas manajer dan atau nilai pasar dari perusahaan.

\section{Riset Empiris Manajemen Laba Pasca Konvergensi IFRS di Indonesia}


Beberapa argument yang melatar belakangi konvergensi ke IFRS adalah perbedaan standar akuntansi akan menjadi hambatan investasi antar negara, ketika terdapat keseragaman standar akuntansi maka investor di negara lain akan memudahkan investor/ calon investor, kreditur/ calon kreditur memahami laporan keuangan perusahaan. Dari sisi akuntansi akan konvergensi ke IFRS meningkatkan kualitas pelaporan laporan keuangan di pasar modal.

Studi-studi empiris sebelumnya menyatakan bahwa adopsi IFRS secara mandatory akan berkaitan dengan likuiditas pasar dan penurunan biaya modal (cost of capital) perusahaan. Selain itu penggunaan praktik akuntansi yang sama di berbagai negara akan memudahkan investor dalam mendeteksi manajemen laba. Ewert dan Wagenhof (2005) menyatakan bahwa standar akuntansi yang semakin ketat dapat menurunkan manajemen laba dan meningkatkan kualitas pelaporan keuangan. Webster dan Thompson (2005) menguji kualitas laba dari perusahaan Kanada yang terdaftar di bursa efek Kanada dan Amerika, dimana perusahaan Kanada menggunakan standar akuntansi yang principle based mempunyai kualitas skrual yang lebih tinggi dibanding perusahaan Amerika yang US GAAP yang rules based.

Barth et.al (2008) menemukan bahwa perusahaan yang menggunakan standar akuntansi keuangan internasional menunjukkan tingkat perataan laba dan manajemen laba yang tinggi. Karena ada korelasi yang tinggi antara laba akuntansi dan harga saham dan return. Lantto (2007) menyatakan bahwa dengan IFRS menaikkan kegunaan informasi laporan keuangandi Finlandia, dengan melakukan survey pada manajer, analis laporan keuangan, dan auditor. Hasil penelitiannya menyatakan bahwa auditor, analis laporan keuangan dan manajer berpendapat bahwa laporan keuangan yang disusun berdasarkan standar IFRS dapat reliable dan relevan.

Penelitian Goncharov dan Zimmerman (2003) menganalisis earning management dengan discretionary accrual pada perusahaan yang laporan keuangannya menggunakan IAS, German GAAP, US GAAP

\section{Riset Empiris Manajemen Laba Pasca Konvergensi IFRS}

Studi empiris menyatakan bahwa adopsi IFRS secara mandatory berkaitan dengan likuiditas pasar dan penurunan biaya modal (cost of capital) perusahaan. Selain itu penggunaan praktik akuntansi yangsama di berbagai Negara akan memudahkan investor dalam manajemen laba. Penelitian Ewert dan Wagenhof (2005) menyatakan bahwa standart akuntansi yang semakin ketat dapat menurunkan manajemen laba dan meningkatkan kualitas pelaporan keuangan. 
Webster dan Thompson (2005) menguji kulaitas laba dari perusahaan Kanada yang terdaftar di bursa efek Kanada dan Amerika dimana perusahaan kanada yang menggunakan standar akuntansi yang Principal Based mempunyai kualitas akrual yang lebih tinggi dibandingkan perusahaan Amerika yang US GAAP yang Rules Based.

Barth et. Al (2008) menemukan bahwa perusahaan yang menggunakan bahwa perusahaan yang menggunakan standar akuntansi keuangan internasional menunujukkan tingkat perataan laba dan manajemen laba dan mempunyai korelasi yang tinggi antara laba akuntansi dan harga saham dan return. Lantto (2007) meneliti apakah IFRS manaikkan kegunaan informasi akuntansi di Finlandia dengan malakukan survey pada manajer, analis laporan keuangan dan auditor hasil penelitiannya menyebutkan bahwa laporan keuangan yang disusun berdasarkan IFRS dapat diandalkan dan relevan.

Leuz (2003) membandingkan asymetri Informasi dan likuiditas pasar dari perusahaan di Jerman yang menggunakan IAS dan US GAAP menemukan bahwa Bid Ask Spred dan volume perdagangan saham antara perusahaan yang menggunakan IAS dan US GAAP tidak berbeda secara signifikan. Zhou et. al meneliti apakah perusahaan Cina setelah mangadopsi IAS mempunyai kualitas laba yang lebih baik dan menemukan bahwa perusahaan yang mengadopsi IAS cenderung tida melakukan manajemen laba.

Cahyati (2010) menyatakan dengan adopsi IFRS maka akan dapat menghasilkan tingkat pelaporan keuangan yang lebih handal dan relevan disbanding sebelum menggunakan IFRS, tingkat perataan laba relative lebih sedikit dibandingkan dengan sebelum menggunakan IFRS.

\section{SIMPULAN}

Peralihan kepada konvergensi IFRS diharapkan akan membawa dampak positif diantaranya adalah dari sisi pelaporan keuangan. Dengan adanya konvergensi IFRS maka akan tercipta suatu pelaporan yang seragam, sehingga memudahkan para pengguna laporan keuangan untuk melakukan kebijakan kebijakan yang terkait dengan performa laporan keuangan suatu perusahaan. Dan hal ini akan membudahkan investor lintas Negara untuk melakukan kebijakan investasinya. Konvergensi IFRS bertujuan untuk mengasilkan suatu laporan keuangan yang relevan dan reliable sehingga akan tercipta suatu laporan yang lebih berkualitas baik untuk asset, kewajiban, modal, pendapatan dan beban. Standar IFRS berbasis prinsip akan lebih condong 
pada pengunaan nilai wajar dan pengungkapan yang lebih banyak dan rinci diharapkan dapat mengurangi adanya praktik manajemen laba.

\section{DAFTAR PUSTAKA}

Barth, M.E.,W.R Landsman and Lang M.H (2008) International Accounting Standard and Accounting Quality. http://www.SSRN diakses tanggal 20 Februari 2011

Cahyati. 2011. Implikasi Tindakan Perataan Laba terhadap Pengambilan Keputusan Oleh Investor. Jurnal Riset Akuntansi dan Komputerisasi Vol 2 No 1 Januari 2011

Ewert dan Wagenhof. 2005. Economic Effects of Tightening Accounting Standards to Restrict Earning Management. The Accounting Review. Vol 80 P. 1101-1124

IAI. 2009. Standar Akuntansi Keuangan. Salemba Emapat

Lantto, Anna Maija. 2007. Does IFRS Improve The Usefullness Of Accounting Information in Code-Law Country. http://www. SSRN diakses pada tanggal 25 Februari 2011

Leuz. C. 2003. IAS versus US GAAP: Asymetri Information Based Evidence From Germany Market. Journal Of Accounting Research Vol. 41 